(c) JBSSR/AIM, 2018, ISSN: 2542-2812

\title{
Tax Reforms and Economic Growth with Reference to SAARC Countries: A Study Note
}

\author{
Bishnu Pokharel ${ }^{1}$
}

\begin{abstract}
This research work is an empirical analysis of Taxation and economic growth SAARC five countries, covering the period 1990-2012. Taxation was disaggregated into: goods and service tax, Personal Income Tax, the other tax, the revenue tax, the Government savings, FDI, Export and Import and they were used independent variables while the GDP per capita income growth was used as dependent variables for measuring economic growth in SAARC. In order to establish interconnection between taxation and economic growth, secondary data were collected from the World Fact Book, SAARC Statistical Bulletin and IMF statistical data. The data collected were analyzed using the Panel Data Regression Analysis and the fixed effect and random effect model regression were used while hypotheses were tested using T-Statistics and Housman Test. The results of the analysis reveal that a significant Negative relationship exists between Taxation and economic growth in SAARC.
\end{abstract}

Keywords: tax revenue, per-capita income growth, panel data regression, Hausman test, five SAARC countries

\section{Introduction}

Economic growth is the basis of quarrel destiny of the different economic variables. The implementation of new production procedures and the overview of new products are the fundamentals of growth process. Through the effect of taxation on the return to the investment or the expected profitability of examination and development taxation can affect what choices are made and ultimately the economic growth.

Lucas $(1988)^{2}$ argued that taxation is levied in money, the method of measurement of taxation and the raised taxes of government expenditure are often highly debated in politics and economics. According to tax forecaster, the weight arranged upon individuals or property owners to support the government expense are exacted by

\footnotetext{
Dr. Pokharel is a Ph.D. Graduate of Economics from Chonbuk National University, South Korea. Corresponding Email: pokbishnu20333@gmail.com

2 Optimal financing by money and taxes of productive and unproductive government spending: effects on economic growth, inflation, and welfare: Aschauer D.A
} 
governmental authority. It is a deliberate expense or contribution, but an enforced contribution, exacted pursuant to government authority.

The first tax involves ownership of the assets of a firm and often defined as the acquisition of percent of the assets of foreign endeavor then it's absorb the choice of a host country for these assets. The assessment of where to invest will depend on asking price circumstances and the extent to which speculation gives special access to the local market and both of these deliberations depend on trade restrictions and other policies in the host country.

The economic growth and taxation are two major aspects for the development of a country. Even though the taxation is the broadband for the progress of a country; it has negative and positive effect for the development of a country. The results of most the researchers in taxation have negative effect in the economic growth in undeveloped countries. However, in some cases, it has positive effect. Basically, the tax has a positive effect in rich countries because there is high per capita income and GDP. So, the research shows the positive effect in rich countries. On the contrary, the SAARC countries with a lower living standard, underdeveloped industrial base, and low $\mathrm{HDI}^{3}$ have negative effect in the economic growth.

The SAARC economy has raised two major questions. First, do the taxation is the cause of underdeveloped? Second, is the high tax rate of a country is the main problem for the development of a country? The research approaches in these questions directly or indirectly by linking taxes to the economic growth using micro and macro data. The Growth rates of SAARC countries are higher during periods when public infrastructure increases relative to other factor ${ }^{4}$ inputs. In addition, if tax policy used to respond in business-cycle fluctuations, the economic growth could also induce a short-run correlation between tax rates and the growth rate. It tries to avoid any short-run business-cycle and focus on the links between tax rates and average growth rates over a long run.

The researcher tries to find out that the effect of taxes on aggregate economic activity is one of the least contested areas in theoretical macro-economics, neoclassical and Keynesian theoretical models e.g. predict has been seen the higher taxes reduce economic activity. Even though there is less agreement on the exact

3 Human Development Index 2013, as included in a United Nations Development ProgrammeHuman Development Report. The latest report was released on 24 July 2014 and compiled based on estimates for 2013. In the 2010 Human Development Report, a further Inequality-adjusted Human Development Index (IHDI) was introduced. While the simple HDI remains useful, "the HDI is the actual level of human development (accounting for inequality)" and "the HDI can be viewed as an index of "potential" human development (or the maximum HDI that could be achieved if there were no inequality)"

4 The Factor of production as like Human Capital ( Capital \& labour) 
mechanisms of generating this result. However, the imperfect, the issue has not been pursued empirically with anything like the dedication that has characterized the much more vigorously debated effects of taxation policy. The most recent important exception has been studied by Romer and Romer $(2007)^{5}$, who construct a novel measure of exogenous. ${ }^{6}$ Because of the negative effect of the taxation in the GDP growth; the undeveloped countries have not given satisfactory results on development. Of course, within a neo-classical ${ }^{7}$ framework, in Solow (1970), the growth simply depends on the accumulation of capital and labor, so that the existing empirical work studying tax effects in investment and labor supply does not capture the relevant effects on growth. In this framework, however, there would be no effects of changes in the development of total factor productivity. The more recent literature on endogenous growth, however, suggests that positive externalities omitted from the traditional neo-classical framework.

SAARC countries' governments collect their revenues through different sources (Nawaz \& Muhammad, 2010) out of these; taxes contribute a significant amount in the public revenues. The government mobilizes its revenues through budget in development activities for the public welfare and interests. People in this region have low per capita income and more than one-third are living under the poverty line in this area. The economic development and prosperity is very low. Foreign dependency and internal leakages have made government think for another option, which is expected to increase the revenue in the countries. Moreover, fiscal deficit has been increasing due to the continuously growing expenditure and the low revenue performance in the least development countries like SAARC countries.

Most of SAARC countries budget have highly resource gap. The expenditure is higher than revenue and foreign aid. The gap is being fulfilled by internal and external loans, which is the main economic problem. The tax and non-tax revenue is the major source of the internal revenue where tax revenue is playing more vital role than non-tax revenue. Tax revenue refers to compulsory transfers to the central government for public purposes. Certain compulsory transfers' fines, penalties, and most social security contributions are excluded.

The experiences of the developed countries clearly indicate that income tax may be one of the major elements for the increment of internal revenue but in developing countries,

5 Romer's early research made him one of the leaders of the New Keynesian economicsKims (1998).

6 The work of Kenneth Arrow (1962)

7 Neoclassical economics is characterized by several assumptions common to many schools of economic thought. There is not a complete agreement on what is meant by neoclassical economics, and the result is a wide range of neoclassical approaches to various problem areas and domainsranging from neoclassical theories of labor to neoclassical theories of demographic changes. 
its contribution has not increased significantly during the long period. It is mentioned above that there is significant resource gap in this area. The gap between income and expenditure is increasing steady state. Even though the governments try to tight in the taxes, the gap has not been changed. The serious problem is same in the process of economic development, it is very necessary to raise its resource of revenue. On the other hand, most of SAARC Countries taxation rate is high then the per capita income, so the economic growth is also low.

The paper is focused on the taxes and its effect in the economic growth either positive or negative. The conclusion of the paper is that the tax is negative effect in the economic growth in poor countries like SAARC countries which has been seen in the results that the income tax and other taxes are not significant at $0.05 \%$ level of economic growth rates but adverse relation with the GDP capita growth rate. The introduction of the paper is followed by the literature review, models and method, the data analysis and the paper is concluded with concluding remarks and the references.

\section{The Literature Review}

The consequence of taxes in GDP has been a widely debated topic over the long antiquity of economic thought specially applied to this theoretical and empirical question. The econometrics analysis has delivered that the result of the taxation in economic growth is differentiate the economy. Most of the world economists show their negative impact in the economy such as SAARC countries. Rest of the world like African countries there is no fact result whether positive or negative.

Claudio et al. (1983) in his article "The impact of taxes on growth and distribution in developed capitalist countries - a cross-national study" published in American Political Science Review, found out that taxes reduce saving but not growth or investment, the scope of public planning in contemporary capitalist economies promoted or hindered economic growth and income distribution. It explores by assessing the impact of various mechanisms for raising government revenues on investment, growth, and income distribution in 22 developed market economy countries. The article considers whether growth and distribution are affected differently by governments' relative reliance on personal and corporate income taxes, social security contributions, property taxes, and value added taxes, or by the relative progressivity of tax mechanisms.

In the Taxation and Economic Growth in Latin America, Canavire-Bacarreza, Jorge Martinez-Vazquez \& Vulovic (2013) concluded that the taxation is among the most common and relevant instruments of policy-makers when thinking about promoting growth, yet there is not compelling evidence regarding its effect in Latin American countries. The findings suggest that the neo-classical growth model describes well the relationship between output and the tax rate in these countries. 
Zahir (2013) in his article "The Economic Performance of SAARC Countries" attempted to examine the impact of trade liberalization over the macro-economic structure of four SAARC member countries Pakistan, India, Bangladesh and Sri Lanka during 1985 to 2006 . The data set consists of a 21 years (1985-2006) of trade variables. The data provides the substantial evidence, which shows the benefits of intra-regional trade expansion: larger markets and fuller utilization of production capabilities, transfer of suitable production technologies, comparative advantage and complementarities. In addition to that, such an arrangement is also expected to foster closer economic ties among member countries and enhance their bargaining power with respect to other countries and economic blocs.

David and Christina (2010) study examined the relationship of taxes and economic growth using broad measures, calculating the overall federal tax burden in the United States as a share of GDP. They carefully examined the narrative of taxation in the United States, and used a methodology designed to avoid the possibility of mistaking cause for effect. The Romers' study found that a tax increase of one percent of GDP reduces real GDP by about three percent within as little as two years.

Again, the Myles (2000) in his article "Taxation and Economic Growth Past research" has enumerated a wide variety of ways in which the tax structure can affect observed economic growth rates. In this section, Myles summarizes these effects, focusing in turn on particular subsets of this literature. Since the objective here is to motivate the empirical work, they focus on those effects that can be measured given the limited information about tax structures in a large panel data set of countries. The implication is that a similar relation would hold in the area of taxation, with raw numbers of tax burdens exaggerating cross-country differences. According to Åsa Johansson ${ }^{8}$, he has been a persistent and largely unbroken upward trend in the ratio of tax to GDP, across the OECD area. Increasing on average in the over six percentage points of GDP followed by some more recent signs of stabilization in the tax revenue in the OECD as a whole. Several countries deviate from this trend. Iceland, Italy, Portugal and Spain all increased their tax to GDP ratios by more than ten percentage points over the period (although all starting from lower than average tax levels), while the increase for the United States was less than three percentage points and the Netherlands experienced a fall in the ratio of over one percentage point. In addition, the Czech Republic, Hungary and the Slovak Republic have reduced their ratios since joining the OECD.

Lee and Roger young Gordon" in "The tax policies affect a country's growth rate, using cross-country data (1970-1997)" found out that statutory corporate tax rates

8 Christopher Heady, Jens Arnold, Bert Brys and Laura Vartia to the OECD working paper 602, 2006

9 'Tax structure and economic growth' analyzed the taxation past theoretical work the higher tax rates should decrease economic growth rates, while the effects of high personal tax rates. 
are significantly negative correlated with cross-sectional differences in average economic growth rates, controlling for various other determinants of economic growth, and other standard tax variables. In fixed-effect regressions, they again find that increases in corporate tax rates lead to lower future growth rates within countries. Their results show that the coefficient estimates suggest that if cut in the corporate tax rate by ten percentage points will raise the annual growth rate by one to two percentage points.

Furceri (2008) in his paper "Tax changes and economic growth: empirical evidence for a panel of OECD countries" investigated the effects of changes in taxes on economic growth. By using annual data (1965 to 2007) for a panel of twenty-six economies, the results show that the effect of an increase in taxes on real GDP per capita is negative and persistent.

\section{The Methodology}

\subsection{The Basic Model}

Gross domestic product (GDP) is an aggregate measure of production equal to the sum of the gross values added of all resident institutional units engaged in production (plus any taxes, and minus any subsidies), on products not included in the value of their outputs $\sim$ OECD. GDP becomes the main tool for measuring a country's economy. At that time (GNP) is the preferred estimate, which differed from GDP in that it measured production by a country's citizens at home and abroad rather than its 'resident institutional units'. The switch to GDP came in the 1990s. The history of the concept of GDP could be distinguished from the history of changes in ways of estimating it. The value added by firms is relatively easy to calculate from their accounts, but the value added by the public sector, by financial industries, and by intangible asset creation is more complex. These activities are increasingly important in developed economies, and the international conventions governing their estimation and their inclusion or exclusion in GDP regularly change in an attempt to keep up within a country. Now the GDP is fluency in the measurement of development.

The total numbers of data are 990 . The study is concerned with past phenomena both depend upon quality and quantity as well as descriptive and analytical. GDP is defined as the final value of all finished goods and services produced between countries borders during a specific time. It calculates investment and net exports at market prices in an open economy. The equation for GDP has been seen in below equation.

$$
\mathrm{Y}=\mathrm{C}+\mathrm{I}+\mathrm{G}+\mathrm{NX} \text {. }
$$

Where $\mathrm{Y}$ means the total output, $\mathrm{C}$ means the Private consumption, I means the investment of all spending on capital, G means the sum of Government spending, and NX is net exports, which mostly negative. Economic growth is the basis of 
future standards of living and prosperity among different nations. As stated earlier, small differences in growth, rates can lead to a substantial difference level of per capita GDP, or standards of living. By using these terms, interchangeably of GDP per capita is the common measure to compare standards of living across countries. In the economic observations, there were various model of growth. The Solow starts with Cobb Douglas ${ }^{10}$ production in a closed economy (1956) is the first model of exogenous technological growth theory. It has shown that taxation is an effect on the level of GDP.

By Cobb Douglas equation

$$
\mathrm{Y}=\mathrm{A} K^{\alpha} L^{1-\alpha}
$$

The Zagler and Durnecker (2003) the model of the taxation and economic growth likewise

$$
Y_{t}=x_{t}^{\alpha} G_{t}^{\beta} L_{t}^{1-\alpha}
$$

Where, $x_{t}$ denotes the aggregate quantity of a composite intermediate input. This aggregate is composed of a set of $\mathrm{n}$ specialized intermediate inputs by the defining relation. $X_{t}^{\alpha}=\sum_{i=1}^{n} x_{i, t}^{\alpha}$, Where $X_{i, t}$ is the quantity of intermediate input in $i$. The input levels minimum cost of production then,

$$
\left.C_{t}=\left(1+\tau_{L}\right) w_{t} L_{t}+\sum_{i=1}^{n}\left(1+\tau_{X i}\right) p_{i, t} X_{i, t}\right)
$$

Where, $\tau_{L}$ are the tax on labor and $\tau_{x i}$, the tax on intermediate goods. Defining an aggregate price index $P_{t}$ and a corresponding aggregate tax $\tau_{X}$ the cost of production function can be written

$C_{t}=\left(1+\tau_{L}\right) w_{t} L_{t}+\left(1+\tau_{x}\right) P_{t} X_{t} \ldots \ldots \ldots \ldots \ldots$ (5) The necessary conditions for cost minimization are solved to show that

$$
\begin{aligned}
& C_{t}=\left(1+\tau_{X}\right) P_{t}=\sum_{i=1}^{n}\left(1+\tau_{x i}\right) p_{i, t}\left[\frac{\alpha}{1-\alpha}\right]^{\frac{\alpha-1}{\alpha}} \\
& x_{i, t}=\frac{\left(\frac{(1+\tau)_{x i P_{i, t}}}{\left(1+\tau_{x}\right) P}\right)}{\alpha-1 X_{t}} X^{t}
\end{aligned}
$$

Each intermediate goods in produced by a different monopolistic firm that maximize profit subject to the demand function (6) this leads to the optimal price.

$$
p_{i, t}=\frac{1}{\alpha}
$$

This implies the aggregate price when all intermediate taxes are equal is

$10 \mathrm{Y}=\mathrm{A} K^{\alpha} L^{1-\alpha}$ 


$$
P_{t}=\frac{1}{\alpha} \frac{1+\tau_{x}}{1+\tau_{X}} n^{(\alpha-1) / \alpha}
$$

A concept of physical capital can be defined by

$$
K_{t}=\sum_{i=1}^{n} x_{i, t}=n^{\frac{\alpha-1}{\alpha}} X_{t}
$$

This allows output to be expressed as

$$
Y_{t}=K_{t}^{\alpha} G_{t}^{\beta}\left(n L_{t}\right)^{1-\alpha}
$$

The Equilibrium capital stock can be shown to be

$$
K_{t}=\alpha^{2}\left(\frac{1-\tau_{y}}{1+\tau_{x}}\right) Y_{t}
$$

This implies that the growth rate is given by

$$
\dot{Y}_{t}=\frac{\beta}{1-\alpha} G_{t} \dot{+} \dot{n}_{t}+\dot{L_{t}}
$$

A constant fraction, $s$, of disposable income is saved and used to finance the activities of R\&D firms. Denoting the tax saving by $\tau_{s}$ and that on R\&D by $\tau_{R D}$ the expenditure on labor for $R \& D$ satisfies.

$$
\left(1-\tau_{s}\right) s Y_{t}^{D}=\left(1+\tau_{R D}\right) w_{t} E_{t}
$$

Innovations arrive at the rate

$$
\dot{n_{t}}=\emptyset h_{t} E_{t}
$$

Where, $h_{t}$ is publicly provided human capital, using these results the per capita growth rate can be found to be

$$
\dot{Y}_{t}-\dot{N}_{t}=\frac{\beta}{1-\alpha} \dot{G}_{t}+\frac{i+\alpha i\left(1+\tau_{\alpha}\right)\left(1-\tau_{\pi}-\tau_{x}\right)}{1+\tau_{g s}+\tau_{i t}+\alpha i\left(1+\tau_{L}\right)\left(1-\tau_{\pi}-\tau_{x}\right)} \frac{h_{t} N_{t}}{n_{t}}
$$

Where, $\tau_{\pi}$ is the profit tax on the producers of intermediate goods. The first term captures the positive effect that taxation has on growth through the financing of the public input. The second term captures tax effects that operate through changes in the level of innovation. Both the tax on R\&D and the tax on saving reduce the growth rate. The tax on R\&D reduces innovation and the tax on saving reduces capital accumulation. The other taxes have an ambiguous effect on growth with the outcome depending on the value of the savings rate, $s$, relative to the value of $1+\tau_{R D}+\tau_{s}$.

\subsection{The Hypothesis Testing}

The estimated hypothesis test ${ }^{11}$ of this paper is

1) A Null hypothesis is $\mathrm{H}_{0}$

$$
\mathrm{H}_{0} \beta_{\mathrm{k}}=\mathrm{c} \text { Where } \mathrm{C} \text { is Constant }
$$

11 The Basic Econometrics Mc. Gra Hill $2^{\text {nd }}$ edition 
2) Alternative hypothesis is $\mathrm{H}_{1}$

$$
\mathrm{H}_{0} \beta_{2}=0 \quad \mathrm{H}_{1} \beta_{2}>0, \quad \mathrm{H}_{0} \beta_{\mathrm{k}} \neq \mathrm{c}
$$

i) $\mathrm{H}_{0} \beta_{2}=0 \quad$ Against $\mathrm{H}_{1} \beta_{2}>0$,

ii) $\mathrm{H}_{1} \beta_{\mathrm{k}}<c$, Rejecting the $\mathrm{H}_{0}$ that $\beta_{\mathrm{k}}=\mathrm{c}, \beta_{\mathrm{k}} \neq \mathrm{c}$

iii) $\mathrm{H}_{1} \beta_{\mathrm{k}}>c$ Rejecting the Null hypothesis $\beta_{\mathrm{k}}=\mathrm{c}$

3) The Test Statistic

$$
\begin{aligned}
& \mathrm{T}=\mathrm{b}_{\mathrm{k}}-\beta_{\mathrm{k}} \\
& \mathrm{b}_{\mathrm{k}}-\beta_{\mathrm{k} / \mathrm{Se}}\left(\mathrm{b}_{\mathrm{k}}\right) \sim \mathrm{t}(\mathrm{N}-2)
\end{aligned}
$$

If the Null hypothesis is $\mathrm{H}_{0} \beta_{2}=\mathrm{c}$ is true then we can substitute $\mathrm{c}$ for $\beta_{\mathrm{k}}$

$$
\mathrm{t}=\frac{\mathrm{b}_{\mathrm{k}}}{\mathrm{se}(\mathrm{bk})} \sim \mathrm{t}(\mathrm{N}-2)
$$

If the null hypothesis is not true then the $t$ Statistic

4) Rejection Region

The large and small are determined by choosing a probability $\alpha$ called the level of significance of the test.

$\alpha=0.01, \quad 0.05, \quad 0.10$

If we reject the null hypothesis when it is true then we commit what is called type 1 error.

If we don't reject null hypothesis that is false then we have committed a type II error.

5) Conclusion

Significant at $5 \%$ level of the other economic indicator in the paper, so we conclude that the taxation is the negative effect with the economic development.

\section{Results and Discussion}

The theoretical analysis is used to meet the specified objectives in the paper along with rational of each step to be adopted by a researcher in studying the problem with certain objectives in view. Czech Republic, Hungary and the Slovak Republic have reduced their ratios since joining the OECD. Lee and Roger young Gordon(1970-1997) explored how tax policies affect a country's growth rate, 
using cross-country data which is based on the Panel data regression as like as the fixed effect model, the random effect model, Housman test and BP-LM test. The SAARC five countries data are proceeded from 1990 to 2012. Per capita growth rate is the dependent variable and the different types of taxes and the economic indicators are independent variables. Mostly four types of taxes are used: the tax revenue, tax in goods and services, income taxes and other taxes. The notation for the model deviations is $\varepsilon$.Formally, the model for multiple linear regressions ${ }^{12}$, given $n$ observations, is

$Y_{i t}=\beta_{0}+\beta_{1} x_{i 1}+\beta_{2} x_{i 2}+\cdots \ldots . .+\beta_{p} X_{i p}+\epsilon_{i}$

The values fit by the equation $b_{0}+b_{1} x_{i 1+\cdots \ldots \ldots \ldots . . .} b_{p} X_{i p}$ are denoted $\hat{y}_{I}$ and the residuals $e_{i}$ are equal to $y_{i}-\hat{y}_{i}$, the difference between the observed and fitted values. The sum of the residuals is equal to zero. The variance $\sigma^{2}$ may be estimated bys $^{2}=\frac{\sum e^{2} i}{n-p-1}$, also known as the mean-squared error (MSE) Mc Graw Hill $2^{\text {nd }}$ edition. The estimate of the standard error $s$ is the square root of the MSE.

Table 1: Panel Data Regression Analysis in SAARC Countries

\begin{tabular}{ccc}
\hline Variables & Coefficient & T values \\
\hline Tax Revenues $(\%$ GDP) & -.1359 & -1.61 \\
Goods and services tax & .0406 & 1.26 \\
Other taxes & .0445 & 0.73 \\
Income taxes & $-.0613^{*}$ & -1.90 \\
FDI & $.6675^{* *}$ & 2.37 \\
Savings & $.3199 * *$ & 6.60 \\
Imports & $.1629 * *$ & 4.32 \\
Exports & $-.1625^{* *}$ & -3.12 \\
Constant & $-2.6465^{* *}$ & -2.28 \\
\hline Total observations & 115 \\
Standard error are in Parentheses & 115 & \\
$*$ Significance at $1 \%$ level $* *$ Significance at $5 \%$ level $* * *$ significance at $10 \%$ level \\
$R^{2}=.4384$ Adjust $R^{2}=0.3960$ Prob $>(\mathrm{F})=0.000$ \\
\hline
\end{tabular}

The (table 1) has seen the co-efficient of the variables are in negative, the intercept value is -2.6465 and the tax variables slopes are 0.044 in other taxes and the 0.0323 in the goods and services. The $R^{2}$ value is only about 0.4348 meaning that the change by 43.48 percent and the adjusted value is 0.3960 . The intercept of the model is -2.665 , the slope of other variables are revenue taxes .1359, FDI.6675, the savings .3198 and the export and import .1628, -.1624 respectively. The variables of other tax, goods and services tax, income tax and tax revenues are

12 In the least-squares model, the best-fitting line for the observed data is calculated by minimizing the sum of the squares of the vertical deviations from each data pointto the line. 
significance in $10 \%$ level. and other variables are significant in $5 \%$ level. In the model, the probability value is 0.0000 , means the $\mathrm{p}$ value is less than five percent.

Table 2: Fixed and Random Effect Model in the SAARC Countries

\begin{tabular}{|c|c|c|c|c|}
\hline \multicolumn{3}{|c|}{ Fixed effect model (Model 1) } & \multicolumn{2}{|c|}{ Random Effect model (Model2) } \\
\hline Variables & Coefficient & $\mathrm{T}$ value & Coefficient & $\mathrm{T}$ value \\
\hline Tax revenue & $\begin{array}{l}-.2400 \\
(.127)\end{array}$ & -1.88 & $\begin{array}{l}-.1359 \\
((.084)\end{array}$ & $-1.61^{*}$ \\
\hline $\begin{array}{c}\text { Tax on Goods \& } \\
\text { services }\end{array}$ & $\begin{array}{r}-.0152 \\
(.044)\end{array}$ & -0.63 & $\begin{array}{l}.0406 \\
(.032)\end{array}$ & 1.26 \\
\hline Other taxes & $\begin{array}{r}-.0377 \\
(.074)\end{array}$ & -0.50 & $\begin{array}{l}.0444 \\
(.061)\end{array}$ & 0.73 \\
\hline Income taxes & $\begin{array}{l}-.0174 \\
(.042)\end{array}$ & -0.41 & $\begin{array}{l}-.0613 \\
(.032)\end{array}$ & $-1.90 *$ \\
\hline FDI & $\begin{array}{l}.2307 \\
(.329)\end{array}$ & 0.70 & $\begin{array}{l}.6675 \\
(.281)\end{array}$ & $2.37 * *$ \\
\hline Savings & $\begin{array}{c}.3484 * * \\
(072)\end{array}$ & 4.80 & $\begin{array}{l}.3198 \\
(.048)\end{array}$ & $6.60 * *$ \\
\hline Imports & $\begin{array}{c}.2107 * * \\
(.086)\end{array}$ & 2.42 & $\begin{array}{l}.1629 \\
(.037)\end{array}$ & $4.32 * *$ \\
\hline Exports & $\begin{array}{c}-.2507 * * \\
(.068)\end{array}$ & -3.65 & $\begin{array}{l}-.1625 \\
(.052)\end{array}$ & $-3.12 * *$ \\
\hline Constant & $\begin{array}{l}.1198 * * \\
(2.076)\end{array}$ & 0.06 & $\begin{array}{c}-2.6465 \\
1.160\end{array}$ & $-2.28 * *$ \\
\hline $\begin{array}{c}F(4,102) \\
\text { Prob }>F\end{array}$ & & & Wald chi2(8) & 82.75 \\
\hline Corr(U_i,Xb) & & & Prob $>$ chi 2 & 0.0000 \\
\hline $\mathrm{R}^{2}$ between & & & $\mathrm{R}^{2}$ between & 0.8818 \\
\hline
\end{tabular}

The fixed effect model, the independent variables are adjusted different economic variables \& the four kinds of taxes but the dependent variables is the GDP growth. In this matter, it is possible to test whether sector specific characteristics are relevant to explain. In the fixed effect model, we have the data from 1990 to 2012. In model one $\mathrm{F}(4,102)$ is $=3.45$ and the coefficients of independent variables are in negative and the coefficients of the slope is 1198. So there is negative relationship between all taxes variables and the GDP growth in SAARC countries. In this model, the $p$-value is 0.0110 , meaning that the $p$ value is less than $5 \%$. The prediction said if the $\mathrm{p}$ value is less than $5 \%$ we reject the null hypothesis and accept the alternative, so in this model, the fixed model is appropriate.

The model two is symbolized the five SAARC countries random effect model table 2 and numbers of observations are 230 . Wald chi square at $5 \%$ level amount and 
the coefficients of the intercept is -2.6465 and the slopes are 0.0406 have goods and services. Other taxes have .044 and the $\mathrm{R}^{2}$ between 0.8818 . In another way, we have the two-tail test hypothesis that each coefficient is different from zero. The probability chi - square is 0.0000 , which is less than five percent.

Table 3: Hausman Test

\begin{tabular}{ccc}
\hline Variables & $\begin{array}{c}\text { Hausman Test in SAARC } \\
\text { Countries }\end{array}$ & $\begin{array}{c}\text { Square root of the (V_b- } \\
\text { V_B })\end{array}$ \\
\cline { 2 - 2 } & b-B & .0958 \\
Tax revenue & -.2400 & .0300 \\
Tax on goods and services & -.0152 & .0432 \\
Other taxes & -.0377 & .0276 \\
Income taxes & -.0174 & .1713 \\
FDI & .2307 & .0539 \\
Savings & .3484 & .0782 \\
Imports & .2107 & .0448 \\
Exports & -.2507 & \\
$C h i^{2}(8)$ & & \\
Prob>Chi & & 18.99 \\
\hline
\end{tabular}

If we get the statistically significant in p-value, we shall use fixed effect model and if not significant then we use appropriate random effect model. Table 3 model shows the probability chi-square value is 0.0149 which is lower than $0.05 \%$.

\section{Concluding Remarks}

The relationship between tax reforms and economic growth in SAARC countries has been investigated element \&compensate for poor infrastructure, limited access to markets, or other weak investment conditions. The attention often focuses on taxation which must be recognized in the study has been asymmetry in variables stemming from countries applying exemption or credit to repatriated profits, the incentive for tax competition should depend on the composition of investing countries. The empirical finding has been seen the increase in tax rate has a negative and persistent effect on GDP per capita growth. The estimates are much closer to those of Furseri and Karras (1999) for a smaller OECD sample. The findings imply that among nine variables, eight variables (Other tax, goods and services tax, tax revenue, income tax, FDI, government savings, exports and imports)are independent variables and GDP per capita growth rate is the dependent variables. It has been concluded that a number of interesting extensions can be pursued which would be useful to examine the effects of tax on variables goods and services, which is related to the VAT evidence on consumption and expenditure. 
There is an asymmetry in the impact of tax differentials on GDP growth, while lower tax rates in the recipient countries fail significantly to attract foreign investment; higher taxes tend to discourage new FDI inflows finally rolled to decrease the GDP growth. Secondly, the impact of positive tax differentials is not homogeneous regarding the double-taxation arrangement in operation in the capital. Tax competition for GDP growth is a reality in today's global environment. Investors routinely compare tax burdens in different locations, as do policy makers, with comparisons typically made across countries that are similar in terms of location and market size. A widely held view is that taxes are likely to matter more in choosing an investment location as non-tax barriers are removed and as national economies converge, where a higher tax burden has matched by well-developed infrastructure, public services and other host country attributes attractive to business, including market size, tax competition from relatively low-tax countries not offering similar advantages may not seriously affect location choice. It is also clear that a low tax encumbrance cannot compensate for a generally weak in GDP growth. Tax is one element and cannot compensate for poor infrastructure, limited access to markets, or other weak investment conditions. In addition, while attention often focuses on taxation, the importance of taxation must be recognized in the study.

Thus, the other taxes, the goods and services taxes were negatively significant in $0.05 \%$ level of significant. However, the income tax was insignificantly negative relationship to the economic growth in the result. The result of the tax variables and non-tax variables in this area has been seen that all tax variables are negative significant with GDP growth. The data analysis of the tax variables is not significant but negative relationship between taxations and GDP growth. Only FDI and exports are significant in the $0.05 \%$ level of significant. These results definitely recommended that if the tax rates have been decreased, the GDP growth rate will be increased in SAARC countries. 


\section{References}

Arrow, K. J. (1972). Economic welfare and the allocation of resources for invention. In Readings in industrial economics(pp. 219-236). Palgrave, London.

Barro, R. J. (1996). Democracy and growth. Journal of economic growth, 1(1), 1-27.

Barro, R. J. (1996). Determinants of economic growth: a cross-country empirical study (No. w5698). National Bureau of Economic Research.

Baum, C. F., Schaffer, M. E., \& Stillman, S. (2011). Using STATA for applied research: reviewing its capabilities. Journal of Economic Surveys, 25(2), 380394.

Castles, F. G., \& Obinger, H. (2007). Social expenditure and the politics of redistribution. Journal of European Social Policy, 17(3), 206-222.

Cheung, Y. W., \& Lai, K. S. (1993). Finite-sample sizes of Johansen's likelihood ratio tests for cointegration. Oxford Bulletin of Economics and statistics, 55(3), 313-328.

Cullen, J. B., \& Gordon, R. H. (2007). Taxes and entrepreneurial risk-taking: Theory and evidence for the US. Journal of Public Economics, 91(7-8), 14791505 .

Easterly, W., \& Rebelo, S. (1993). Fiscal policy and economic growth. Journal of monetary economics, 32(3), 417-458.

Easterly, W., \& Rebelo, S. (1993). Fiscal policy and economic growth. Journal of monetary economics, 32(3), 417-458.

Gale, W. G., \& Orszag, P. R. (2003). An Economic Assessment of Tax Policy in the Bush Administration, 2001-2004. BCL Rev., 45, 1157.

Gentry, W. M., \& Hubbard, R. G. (2000). Tax policy and entrepreneurial entry. American Economic Review, 90(2), 283-287.

Gordon, R. H., \& Cullen, J. B. (2002). Taxes and entrepreneurial activity: Theory and evidence for the US (No. w9015). National Bureau of Economic Research.

Johansson, O. Å., Heady, C., Arnold, J., Brys, B., \& Vartia, L. (2008). Tax and economic growth" Economics Department(No. 620). Working Papers.

Kandel, P. (2000). Capital Income Taxation in Nepal: An Analysis of Effective Burden. Nepalese Journal of Government Revenue, 20(1), 228-241. 
Karras, G. (2013). Inflation and the Great Moderation: Evidence from a Large Panel Data Set. International Journal of Economic Sciences and Applied Research, 6(3), 7-19.

Katz, C. J., Mahler, V. A., \& Franz, M. G. (1983). The impact of taxes on growth and distribution in developed capitalist countries: A cross-national study. American Political Science Review, 77(4), 871-886.

Kim, S. J. (1998). Growth effect of taxes in an endogenous growth model: to what extent do taxes affect economic growth?. Journal of Economic Dynamics and Control, 23(1), 125-158.

Lee, Y., \& Gordon, R. H. (2005). Tax structure and economic growth. Journal of public economics, 89(5-6), 1027-1043.

Lucas Jr, R. E. (1988). On the mechanics of economic development. Journal of monetary economics, 22(1), 3-42.

Mankiw, N. G., Phelps, E. S., \& Romer, P. M. (1995). The growth of nations. Brookings papers on economic activity, 1995(1), 275-326.

Mendoza, E. G., Milesi-Ferretti, G. M., \& Asea, P. (1997). On the ineffectiveness of tax policy in altering long-run growth: Harberger's superneutrality conjecture. Journal of Public Economics, 66(1), 99-126.

Myles, G. D. (2000). Taxation and economic growth. Fiscal studies, 21(1), 141168.

OECD. (2008). Tax Effects on Foreign Direct Investment: Recent Evidence and Policy Analysis.

Ogbonna, G. N., \& Ebimobowei, A. (2012). Impact of tax reforms and economic growth of Nigeria: A time series analysis. Current Research Journal of Social Sciences, 4(1), 62-68.

Pack, H. (1994). Endogenous growth theory: intellectual appeal and empirical shortcomings. Journal of Economic Perspectives, 8(1), 55-72.

Padovano, F., \& Galli, E. (2002). Comparing the growth effects of marginal vs. average tax rates and progressivity. European Journal of Political Economy, 18(3), 529-544.

Romer, C. D., \& Romer, D. H. (2010). The macroeconomic effects of tax changes: estimates based on a new measure of fiscal shocks. American Economic Review, 100(3), 763-801. 
Solow, R. M. (1956). A contribution to the theory of economic growth. The quarterly journal of economics, 70(1), 65-94.

Stewart, K. G. (2005). Introduction to applied econometrics. Belmont, CA: Thomson Brooks/Cole.

Torres-Reyna, O. (2007). Panel data analysis fixed and random effects using Stata (v. 4.2). Data \& Statistical Services, Priceton University.

Zaheer, R. (2013). The economic performance of SAARC member countries. Research on Humanities and Social Sciences, 3(5), 201-214. 